University of Nebraska - Lincoln

DigitalCommons@University of Nebraska - Lincoln

Agronomy \& Horticulture -- Faculty Publications

Agronomy and Horticulture Department

2009

\title{
Evaluation of Glyphosate-Tolerant and Conventional Alfalfa Weed Control Systems during the First Year of Establishment
}

Robert Wilson Jr.

University of Nebraska-Lincoln, rwilson1@unl.edu

Paul Burgener

University of Nebraska-Lincoln, pburgener2@unl.edu

Follow this and additional works at: https://digitalcommons.unl.edu/agronomyfacpub

Part of the Plant Sciences Commons

Wilson, Robert Jr. and Burgener, Paul, "Evaluation of Glyphosate-Tolerant and Conventional Alfalfa Weed Control Systems during the First Year of Establishment" (2009). Agronomy \& Horticulture -- Faculty Publications. 328.

https://digitalcommons.unl.edu/agronomyfacpub/328

This Article is brought to you for free and open access by the Agronomy and Horticulture Department at DigitalCommons@University of Nebraska - Lincoln. It has been accepted for inclusion in Agronomy \& Horticulture -Faculty Publications by an authorized administrator of DigitalCommons@University of Nebraska - Lincoln. 


\title{
Evaluation of Glyphosate-Tolerant and Conventional Alfalfa Weed Control Systems during the First Year of Establishment
}

\author{
Robert G. Wilson and Paul A. Burgener*
}

\begin{abstract}
A field trial was conducted for 3 yr (2005 through 2007) near Scottsbluff, NE, to examine weed control, crop safety, forage production, and economics of glyphosate-tolerant and conventional alfalfa establishment systems. Glyphosate applied to alfalfa at the unifoliate growth stage provided $67 \%$ weed control and was similar to imazamox applied at the two-trifoliate leaf stage. Delaying glyphosate application until alfalfa had reached the two-trifoliate growth stage improved weed control to $83 \%$, and weed control was similar to imazamox plus 2,4-DB and imazethapyr plus 2,4-DB. Imazamox and imazethapyr caused minor crop injury, and the addition of bromoxynil or 2,4-DB to both herbicides further decreased crop safety. Weeds were most competitive with the first forage harvest and reduced relative feed value, crude protein, and value (dollars per $\mathrm{t}$ ) of forage compared to forage that had been treated with herbicides. The total forage yield for the season consisted of three forage harvests and was greatest when no herbicides were applied. The total forage yield of plots treated with glyphosate at the two-trifoliate growth stage was greater than that of plots treated with imazamox or imazethapyr in combination with bromoxynil. When glyphosate was applied at the two-trifoliate growth stage, seasonal forage yield was similar to forage treated with imazamox, imazethapyr, or both herbicides in combination with 2,4-DB. When herbicide was applied to alfalfa at the two-trifoliate growth stage, the net return from using glyphosate with a glyphosate-tolerant alfalfa variety or utilizing imazamox with a conventional alfalfa variety were similar at $\$ 742$ and $\$ 743 /$ ha, respectively.

Nomenclature: 2,4-DB; bromoxynil; glyphosate; imazamox; imazethapyr; alfalfa, Medicago sativa L. 'RR04BD-2411', 'Rebound 4.2'.
\end{abstract}

Key words: Herbicide-tolerant crops, forage quality, weed management.

Heavy infestations of weeds in a new seeding of alfalfa can reduce stand, yield, and quality (Cords 1973; McCarty and Sand 1961). Weeds that emerge with alfalfa are generally considered to be most competitive with the crop compared to weeds that emerge later in the growing season (Fischer et al. 1988). Early weed competition can cause alfalfa seedlings to die and even if weed top growth is removed by harvest, the vigor of the alfalfa plant can be reduced and reflected in declines in forage yields in later cuttings (McCarty and Sand 1961; Wilson 1986). In new seedings of alfalfa, the first cutting of forage generally contains the greatest quantity of weeds and weed biomass in later cuttings is much less of a problem (Wilson 1986). Removing weeds can increase alfalfa growth but can also reduce the total forage yield. This can be beneficial if weeds are of inferior nutritive value, influence the flavor of milk or meat, cause palatability problems, or are poisonous to livestock. However, when some weeds (such as common lambsquarters [Chenopodium album L.] and redroot pigweed [Amaranthus retroflexus L.]) are cut at relatively early stages of maturity their nutritive value is similar to alfalfa and removal of these weeds will reduce forage yield (Marten and Andersen 1975). Therefore, the anticipated market for the forage and the density and types of weeds will dictate the acceptability of weeds in alfalfa.

In an effort to reduce early-season weed competition and improve forage quality, herbicides have been utilized in PPI and POST applications during alfalfa establishment. Registered herbicides are generally safe to alfalfa, but in some situations have been shown to cause crop injury. Peregrine

\footnotetext{
DOI: $10.1614 /$ WT-08-082.1

* Professor, Department of Agronomy and Horticulture and Research Analyst, Department of Agricultural Economics, University of Nebraska-Lincoln, Scottsbluff, NE 69361. Corresponding author’s E-mail: rwilson@unl.edu
}

and Norris (1988) found that seedling alfalfa exhibited increased phytotoxicity from bromoxynil when POST applications were made when air temperatures were greater than $28 \mathrm{C}$. Bromoxynil generally caused more crop injury to seedling alfalfa than 2,4-DB amine, but both herbicides had the potential to injure the crop (Tonks et al. 1991). Imazethapyr injured seedling alfalfa and injury increased as application rate increased from 0.07 to $1.4 \mathrm{~kg} / \mathrm{ha}$ (Wilson 1994). Imazamox can also be utilized for POST weed control in seedling alfalfa, and like imazethapyr, crop injury is variable and is speculated to be linked to plant stress at the time of treatment (Canevari et al. 2003; McCordick et al. 2008).

The introduction of glyphosate-tolerant crops has created new postemergence weed control opportunities for herbicides traditionally considered nonselective. Glyphosate-tolerant alfalfa is one of the more recent glyphosate-tolerant crop introductions to North American agriculture. One of the benefits of this technology is that alfalfa plants are tolerant to glyphosate at all stages of growth (McCaslin et al. 2000). Preliminary research shows no negative effects from glyphosate on crop vigor, yield, or quality (Orloff et al. 2003). Most researchers have taken the approach of comparing weed control and forage yield obtained with imazamox or imazethapyr, two herbicides presently popular for POST weed control in new seedings of alfalfa, to glyphosate applied to glyphosate-tolerant alfalfa. McCordick et al. (2008) found the increased crop safety of glyphosate compared to imazamox contributed to greater alfalfa yields at the first harvest. They also found glyphosate to be more effective than imazamox in suppressing weeds in new seedings of alfalfa.

Research was initiated to compare crop safety and weed control between glyphosate and imazethapyr or imazamox weed control programs. The study was also designed to 
examine forage yield and quality following different degrees of weed removal in glyphosate-tolerant and conventional alfalfa and to compare the economic aspects of glyphosate applied to glyphosate-tolerant alfalfa with that of conventional herbicide programs applied to a near-equivalent conventional cultivar.

\section{Materials and Methods}

Field experiments were established in the spring of 2005 through 2007 at the University of Nebraska Panhandle Research and Extension Center located near Scottsbluff, NE. Experiments were located in a different field each of the $3 \mathrm{yr}$ and the soil was a Glenberg sandy loam (Ustic Torrifluvents) with a $\mathrm{pH}$ that ranged from 8 to 8.2 and organic-matter content that ranged from 0.9 to $1.3 \%$. The experimental design was a randomized complete block with four replications. There were 14 treatments that consisted of six glyphosate treatments where glyphosate was applied at different rates and timings, six conventional treatments with either imazamox or imazethapyr applied alone or in combination with bromoxynil or 2,4-DB amine, and two no-herbicide treatments. Glyphosate treatments and the nontreated glyphosate-resistant alfalfa plot were seeded with the glyphosate-tolerant alfalfa variety 'RR04BD-2411', whereas nonglyphosate treatments and the nontreated conventional alfalfa plot were seeded with 'Rebound 4.2 ', ${ }^{1}$ which was a near-equivalent conventional variety. The plot area was disced and packed in early April, and alfalfa was seeded the third week of April at a seeding rate of $9 \mathrm{~kg} / \mathrm{ha}$ with a Tye ${ }^{2}$ drill. A single plot measured $3.4 \mathrm{~m}$ wide by $15 \mathrm{~m}$ long and was planted with two passes of the drill. The study area was fertilized as needed with $\mathrm{P}_{2} \mathrm{O}_{5}$ and sulfur, based on soil test recommendations from the University of Nebraska soil testing lab. Alfalfa was irrigated if rainfall did not occur within $2 \mathrm{~d}$ of planting. An overhead irrigation system was utilized to irrigate the crop when needed throughout the growing season.

Average air temperatures for the period of March through September were 15, 16, and 17 C for 2005, 2006, and 2007 respectively, compared to the long-term average of $15 \mathrm{C}$ for Scottsbluff, NE. Precipitation for the 7-mo period declined from $293 \mathrm{~mm}$ in 2005 to $206 \mathrm{~mm}$ in 2006, and to $121 \mathrm{~mm}$ in 2007, and are below the long-term average of $312 \mathrm{~mm}$.

Herbicides were broadcast applied at a spray volume of $197 \mathrm{~L} / \mathrm{ha}$ and a pressure of $248 \mathrm{kPa}$ through $11002 \mathrm{VS}$ nozzle tips $^{3}$ with a tractor-mounted sprayer. Spray additives were combined with the spray solution according to manufacturers' suggestions for herbicides applied POST: glyphosate, imazamox, and imazethapyr (Table 1). Glyphosate was applied to alfalfa at the unifoliate, two-trifoliate, or four-trifoliate growth stage, and imazamox and imazethapyr alone or in combination with bromoxynil or $2,4-\mathrm{DB}$ were applied at the two-trifoliate growth stage.

Visual estimates of alfalfa injury were recorded $25 \mathrm{~d}$ after treatment (DAT) with the use of a rating scale of 0 (no injury) to 100 (completely killed). Numbers of alfalfa plants and live weeds were counted in a $1-\mathrm{m}^{2}$ quadrant placed in the center of each plot during late June. The first alfalfa harvest occurred at the bud to first bloom growth stage during the first week of July. Plots were harvested a second and third time the first week
Table 1. Description of herbicide treatments, alfalfa growth stage at the time of application, and alfalfa variety at Scottsbluff, NE, from 2005 through 2007.

\begin{tabular}{|c|c|c|c|c|}
\hline \multirow[b]{2}{*}{ Treatment ${ }^{a}$} & \multicolumn{2}{|c|}{ Rate } & \multicolumn{2}{|c|}{ Alfalfa } \\
\hline & ae & ai & Growth stage & Variety \\
\hline & -1 & 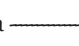 & & \\
\hline No herbicide & - & - & - & RR04B2-2411 \\
\hline Glyphosate & 0.84 & & Unifoliate & RR04B2-2411 \\
\hline Glyphosate & 0.84 & & Unifoliate & RR04B2-2411 \\
\hline glyphosate & 0.84 & & Four trifoliate & \\
\hline Glyphosate & 1.25 & & Two trifoliate & RR04B2-2411 \\
\hline Glyphosate & 1.25 & & Two trifoliate & RR04B2-2411 \\
\hline glyphosate & 1.25 & & Eight trifoliate & \\
\hline Glyphosate & 1.68 & & Four trifoliate & RR04B2-2411 \\
\hline Glyphosate & 1.68 & & Four trifoliate & RR04B2-2411 \\
\hline glyphosate & 1.68 & & Sixteen trifoliate & \\
\hline Imazamox & & 0.036 & Two trifoliate & Rebound 4.2 \\
\hline Imazamox + & & $\begin{array}{l}0.036 \\
0.25\end{array}$ & Two trifoliate & Rebound 4.2 \\
\hline $\begin{array}{l}\text { Imazamox }+ \\
\text { 2,4-DB }\end{array}$ & 0.56 & $\begin{array}{l}0.29 \\
0.036\end{array}$ & Two trifoliate & Rebound 4.2 \\
\hline Imazethapyr & & 0.053 & Two trifoliate & Rebound 4.2 \\
\hline $\begin{array}{r}\text { Imazethapyr }+ \\
\text { bromoxynil }\end{array}$ & & 0.053 & Two trifoliate & Rebound 4.2 \\
\hline $\begin{array}{l}\text { Imazathoxynil } \\
\text { 2,4-DB }\end{array}$ & 0.56 & $\begin{array}{l}0.28 \\
0.053\end{array}$ & Two trifoliate & Rebound 4.2 \\
\hline
\end{tabular}

${ }^{a}$ Ammonium sulfate was combined with glyphosate at a rate of $2 \%$ weight to volume, and nonionic surfactant plus liquid nitrogen $(28-0-0)$ were added at $0.25 \%$ plus $1 \%$ volume to volume to nonglyphosate treatments.

of August and September, respectively. Alfalfa and weeds were harvested together with a plot swather ${ }^{4}$ that cut a 1 -m-wide swath through the center of each plot for a distance of $15 \mathrm{~m}$. A random sample ranging from 500 to $700 \mathrm{~g}$ was removed from the harvester after the forage was collected from each plot, and the water content was determined gravimetrically. After being dried, samples were ground in a Wiley mill to pass through a screen containing $17 \mathrm{mesh} / \mathrm{cm}$, and then sent to the University of Nebraska forage laboratory for analysis to determine forage crude protein $(\mathrm{CP})$, acid detergent fiber (ADF), and neutral detergent fiber (NDF). The relative feed value index (RFV) of the forage estimates digestible dry matter (DDM) of the forage from $\mathrm{ADF}$, and calculates the dry-matter intake potential from NDF (Jeranyama and Garcia 2004). Alfalfa and weeds were not separated prior to analysis and forage yields were expressed on a $12 \%$ moisture basis.

Economic returns were calculated from establishment-year forage yield, RFV, alfalfa hay price, and selected variable costs to determine the net return over herbicide, seed, and harvest costs for five selected herbicide treatments with the use of a partial budgeting procedure. Gross return per hectare was determined with the use of the mean establishment-year forage yield and a 3-yr average (2005 to 2007) of the annual average alfalfa hay prices reported for western Nebraska by the USDA Agriculture Marketing Service (Anonymous 2008). The University of Nebraska custom rates were used to determine the cost of forage harvest, and the University of Nebraska Guide for Weed Management was the source for herbicide costs (Jose and Malchow 2006; University of Nebraska 2007). The 2006 University of Nebraska Crop Budgets were the source for alfalfa seed price, and industry sources provided the information on the glyphosate-tolerant 


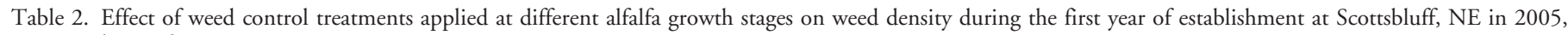
2006 , and $2007 .^{\mathrm{a}}$

\begin{tabular}{|c|c|c|c|c|c|c|c|c|}
\hline \multirow[b]{2}{*}{ Treatment ${ }^{\mathrm{b}}$} & \multicolumn{2}{|c|}{ Rate } & \multirow[b]{2}{*}{ Alfalfa growth stage } & \multicolumn{5}{|c|}{ Weed density measured in late June } \\
\hline & ae & ai & & AMARE & CHEAL & KCHSC & SOLSA & Total \\
\hline & \multicolumn{2}{|c|}{$-\mathrm{kg} / \mathrm{ha}$} & & \multicolumn{5}{|c|}{ - plants $/ \mathrm{m}^{2}$} \\
\hline No herbicide & - & - & - & 4 & 280 & 1 & 9 & 294 \\
\hline Glyphosate & 0.84 & & Unifoliate & 2 & 87 & 1 & 7 & 97 \\
\hline Glyphosate & 0.84 & & Unifoliate & & & & & \\
\hline glyphosate & 0.84 & & Four trifoliate & 3 & 55 & 1 & 0 & 59 \\
\hline Glyphosate & 1.25 & & Two trifoliate & 2 & 39 & 2 & 8 & 51 \\
\hline Glyphosate & 1.25 & & Two trifoliate & & & & & \\
\hline glyphosate & 1.25 & & Eight trifoliate & 1 & 35 & 1 & 1 & 38 \\
\hline Glyphosate & 1.68 & & Four trifoliate & 6 & 35 & 0 & 1 & 42 \\
\hline Glyphosate & 1.68 & & Four trifoliate & & & & & \\
\hline glyphosate & 1.68 & & Sixteen trifoliate & 1 & 14 & 0 & 2 & 17 \\
\hline Imazamox & & 0.036 & Two trifoliate & 1 & 76 & 26 & 1 & 104 \\
\hline Imazamox + & & 0.036 & & & & & & \\
\hline bromoxynil & & 0.25 & Two trifoliate & 18 & 55 & 1 & 0 & 74 \\
\hline Imazamox + & & 0.036 & & & & & & \\
\hline 2,4-DB & 0.56 & & Two trifoliate & 2 & 33 & 3 & 1 & 39 \\
\hline Imazethapyr & & 0.053 & Two trifoliate & 1 & 96 & 1 & 2 & 100 \\
\hline Imazethapyr + & & 0.053 & & & & & & \\
\hline bromoxynil & & 0.28 & Two trifoliate & 7 & 32 & 0 & 0 & 39 \\
\hline Imazethapyr + & & 0.053 & & & & & & \\
\hline 2,4-DB & 0.56 & & Two trifoliate & 3 & 34 & 2 & 1 & 40 \\
\hline LSD $(0.05)$ & & & & 8 & 40 & 8 & 6 & 43 \\
\hline
\end{tabular}

abbreviations: AMARE, redroot pigweed; CHEAL, common lambsquarters; KCHSC, kochia; SOLSA, hairy nightshade.

${ }^{\mathrm{b}}$ Ammonium sulfate was combined with glyphosate at a rate of $2 \%$ weight to volume, and nonionic surfactant plus liquid nitrogen (28-0-0) were added to imazamox and imazethapyr treatments at 0.25 and $1 \%$ volume to volume, respectively.

alfalfa seed premium (Selley et al. 2006). All costs of production other than weed control, seed costs, and forage harvest were assumed to be equal across treatments.

Data were subjected to ANOVA with the use of the PROC MIXED procedure of SAS $8.02 .{ }^{5}$ Normality of residuals and homogeneity of variances were evaluated and data were transformed when necessary. Interactions between weed control treatments and years were not significant for all variables except common lambsquarters and redroot pigweed density, alfalfa density, and forage crude protein. The interaction effects were small relative to the treatment effect and the ranking of weed control treatments over years was stable, so the interaction was ignored and the data were pooled and subjected to analysis of variance (Gomez and Gomez 1984). Year was considered a fixed factor. Means were separated with the use of a Fisher's protected least significant difference at an alpha level of 0.05 .

\section{Results and Discussion}

Alfalfa density, forage yield, and weed density did not differ significantly in the no-herbicide treatment seeded with the glyphosate-tolerant alfalfa variety 'RR04BD-2411' and the nonglyphosate tolerant variety 'Rebound 4.2 '. Because the data were similar in the two nontreated areas, the data were combined to provide a single no-herbicide treatment.

Weed Response. Common lambsquarters was the dominant weed present in the study area each year with an average density of 280 plants $/ \mathrm{m}^{2}$ where no herbicide was applied (Table 2). Redroot pigweed, kochia [Kochia scoparia (L.)
Schrad.], and hairy nightshade (Solanum physalifolium Rusby) were also present at average densities of 4,1 , and 9 plants $/ \mathrm{m}^{2}$ respectively, in nontreated areas. Weed density fluctuated over the $3 \mathrm{yr}$, with hairy nightshade (Solanum physalifolium Rusby) density greatest in 2005 and common lambsquarters, redroot pigweed, and kochia more prevalent in 2006. Even though weed density varied over years, the response to herbicides was similar. Common lambsquarters began emerging with seedling alfalfa and continued to emerge through May. At the unifoliate growth stage of alfalfa, common lambsquarters that had emerged with alfalfa was approximately $3 \mathrm{~cm}$ tall.

Glyphosate at $0.84 \mathrm{~kg} / \mathrm{ha}$ applied at the unifoliate growth stage controlled $69 \%$ of the final common lambsquarters population when compared to the no-herbicide treatment (Table 2). Delaying the glyphosate treatment $10 \mathrm{~d}$ until the crop reached the two-trifoliate stage resulted in an $86 \%$ reduction in common lambsquarters density compared to the no-herbicide treatment. The improvement in weed control was probably the result of more of the common lambsquarters population being exposed to herbicide at the later date and increase in the glyphosate rate from 0.84 to $1.25 \mathrm{~kg} / \mathrm{ha}$. Further delaying glyphosate treatment until the four-trifoliate growth stage did not result in an improvement in common lambsquarters control. Treating alfalfa with glyphosate at $1.68 \mathrm{~kg} / \mathrm{ha}$ at the four-trifoliate and again at the sixteentrifoliate growth stage showed a trend for a further reduction in common lambsquarters density. When compared to the no-herbicide treatment, reductions in hairy nightshade density with glyphosate applied at the unifoliate or two-trifoliate growth stage were greatest when glyphosate was applied twice. This may have been the result of the first glyphosate treatment 
reducing common lambsquarters density, which allowed hairy nightshade development, which then allowed the weed to be responsive to the second glyphosate treatment.

Compared to the no-herbicide treatment, common lambsquarters density was reduced $73 \%$ from imazamox applied to alfalfa at the two-trifoliate growth stage (Table 2). The reduction in common lambsquarters density with imazamox allowed the kochia population to expand. This may have been a result of the dense common lambsquarters population reducing the development of kochia and with the decline in common lambsquarters, kochia was provided more area to develop. The suspected tolerance of the kochia population to herbicides with an acetolactate synthase inhibitor mode of action may be another reason the kochia population increased. The addition of bromoxynil to imazamox showed a trend for a further reduction in common lambsquarters density, a reduction in kochia density, and an increase in the redroot pigweed population. The removal of two competing weeds with imazamox plus bromoxynil allowed redroot pigweed an opportunity to develop. A combination of imazamox plus 2,4DB provided the greatest reduction of common lambsquarters when compared to the no-herbicide treatment, a reduction in kochia density compared to imazamox, and a reduction in redroot pigweed density compared to imazamox plus bromoxynil.

POST application of imazethapyr reduced common lambsquarters density $66 \%$ compared to the no-herbicide treatment (Table 2). In previous experiments imazethapyr has been shown to provide less common lambsquarters suppression than imazamox (Nelson et al. 1998). The reduction in total weed density was similar between imazethapyr and imazamox. A combination of imazethapyr with 2,4-DB provided similar weed suppression to imazamox plus 2,4-DB.

Glyphosate at $0.84 \mathrm{~kg} / \mathrm{ha}$ applied to alfalfa at the unifoliate growth stage provided weed suppression similar to imazamox applied at the two-trifoliate leaf stage (Table 2). Delaying glyphosate treatment until alfalfa had reached the twotrifoliate growth stage and increasing the glyphosate rate to $1.25 \mathrm{~kg} / \mathrm{ha}$ improved weed control and weed suppression to a level similar to imazamox plus 2,4-DB or imazethapyr plus 2,4-DB.

Alfalfa Stand and Injury. Alfalfa density was reduced in the no-herbicide treatment compared to all herbicide treatments (Table 3). The early-season weed suppression provided by all herbicide treatments allowed more alfalfa plants to become established compared to nontreated areas. The results obtained in this study are similar to other experiments that have demonstrated that early season weed or cover crop competition with seedling alfalfa can impact stand densities and alfalfa stands improved following weed or cover crop control (Becker et al. 1998; McCordick et al. 2008)

Imazamox and imazethapyr caused minor injury to alfalfa seedlings, which increased with the addition of bromoxynil or 2,4-DB to either herbicide (Table 3). Past research has also demonstrated the POST treatment of bromoxynil to seedling alfalfa can cause crop injury (Peregrine and Norris 1988). Injury was shown to increase when air temperatures were greater than $28 \mathrm{C}$ and treatments were made in the morning. In these studies, herbicide treatments were made in midmorning when air temperatures were 13,27 , and $25 \mathrm{C}$ in
2005, 2006, and 2007, respectively. Even though air temperatures did not exceed $28 \mathrm{C}$, herbicide combinations with bromoxynil still caused moderate crop injury (Table 3). Mixing imazamox or imazethapyr with 2,4-DB caused less crop injury than mixtures with bromoxynil. Weed control was similar between mixtures with bromoxynil and 2,4-DB, but the improved crop safety with 2,4-DB makes 2,4-DB plus imazamox or imazethapyr more desirable than bromoxynil plus imazamox or imazethapyr.

Forage Production. Weeds were most prevalent in the first harvest and forage production was greatest where no herbicide was utilized for weed suppression (Table 3). Herbicide application reduced weed density with a corresponding reduction in total forage yield. Weed density averaged 294 plants $/ \mathrm{m}^{2}$ where no herbicide was applied and 59 plants $/ \mathrm{m}^{2}$ following two applications of glyphosate at the unifoliate and four-trifoliate growth stage. First-harvest forage yield for these two treatments was 6.1 and $2.3 \mathrm{t} / \mathrm{ha}$, respectively. In theory, applying glyphosate at the unifoliate and again at the fourtrifoliate growth stage should result in minimal weed competition with alfalfa. Subtracting the first-harvest glyphosate forage yield from the yield of the no-herbicide treatment showed a difference of $3.8 \mathrm{t} / \mathrm{ha}$, which suggests that approximately $62 \%$ of the forage yield in the no-herbicide treatment was composed of weeds, especially common lambsquarters. First-harvest forage quality was higher with all the herbicide treatments compared to the control. Past research has shown that in comparison to alfalfa, redroot pigweed and common lambsquarters harvested 50 to $60 \mathrm{~d}$ after alfalfa seeding can have nutrient composition and digestibility equivalent to high-quality alfalfa (Marten and Andersen 1975). In this study redroot pigweed and common lambsquarters were harvested approximately $70 \mathrm{~d}$ after alfalfa seeding and were probably more mature compared to weeds harvested in the study conducted by Marten and Andersen (1975). Results from this study suggest that large quantities of common lambsquarters mixed with alfalfa reduced forage quality compared to alfalfa where a portion of the common lambsquarters population had been removed with glyphosate.

First-harvest forage yield declined as the first application of glyphosate was delayed; glyphosate applied at the unifoliate or four-trifoliate growth stages resulted in first harvest-forage yields of 3.8 and $2.0 \mathrm{t} / \mathrm{ha}$, respectively (Table 3 ). The yield reduction was the result of an improvement in weed control, because weed density declined from 97 to 42 plants $/ \mathrm{m}^{2}$, as glyphosate application was delayed from the unifoliate to four-trifoliate growth stage (Table 2).

Several researchers have shown that early weed or companion crop competition with seedling alfalfa can reduce alfalfa vigor and subsequent alfalfa yield (Curran et al. 1993; Simmons et al. 1995). Forage yields in the second harvest of this study were reduced where weeds were allowed to compete prior to the first harvest compared to alfalfa treated with glyphosate at the unifoliate and again at the four-trifoliate growth stages. Weed removal during early stages of alfalfa establishment can improve alfalfa stand and improve firstharvest forage quality, which are all positive points for weed removal. However, on the negative side, weed removal can reduce first harvest forage yield. 
Table 3. Effect of weed control treatments applied at different alfalfa growth stages on forage production and quality during the first year of establishment at Scottsbluff, NE in 2005, 2006, and 2007.

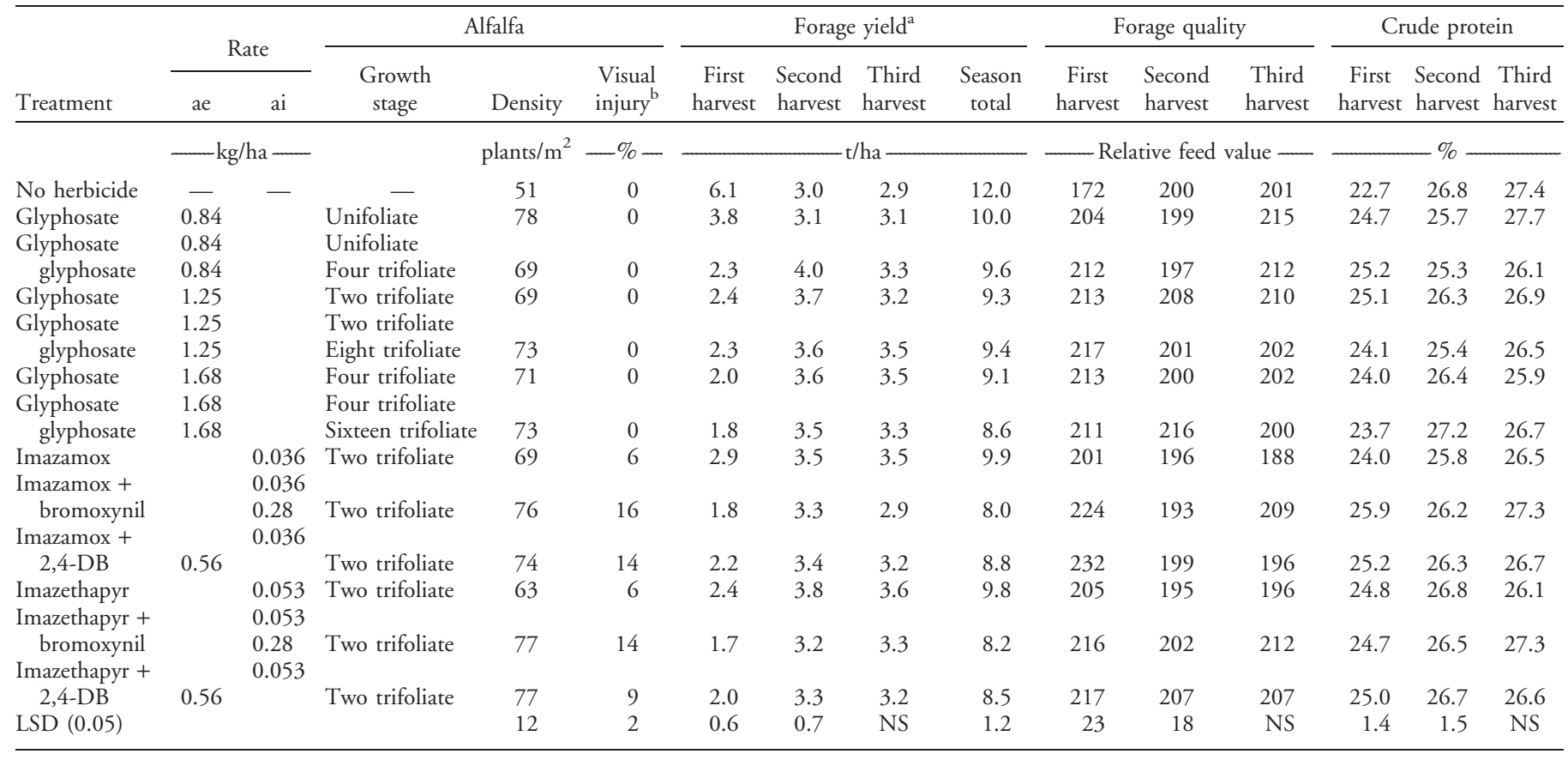

${ }^{a}$ Forage yield was a combination of alfalfa and weeds.

${ }^{\mathrm{b}}$ Visual estimates of alfalfa injury were recorded $25 \mathrm{~d}$ after treatment with a rating scale of 0 (no injury) to 100 (completely killed).

Applying glyphosate only at the unifoliate growth stage removed approximately two-thirds of the weed population, which resulted in an increase of first-harvest forage yield of $1.5 \mathrm{t} / \mathrm{ha}$ over that obtained when glyphosate was applied at the unifoliate and again at the four-trifoliate growth stage (Table 3). However, the weeds remaining with alfalfa prior to the first harvest when only a single application of glyphosate was applied at the unifoliate growth stage still had an effect on alfalfa vigor, which resulted in a reduction in second-harvest yield compared to the forage yield obtained when glyphosate was applied at the unifoliate and again at the four-trifoliate growth stages. Glyphosate treatments that reduced weed density $80 \%$ or more had similar first, second, and third harvest yields, RFV, and crude protein content.

First, second, and third harvest forage yields, RFV, and crude protein content were similar between plots treated with imazamox and imazethapyr (Table 3). The addition of bromoxynil to both imazamox and imazethapyr increased crop injury and reduced weed density, which resulted in a reduction in first-harvest forage yield compared to imazamox or imazethapyr applied alone. In comparison to imazamox, the combination of imazamox plus bromoxynil increased the RFV and crude protein of the first-forage harvest, which was probably the result of reduced weed density and early-season crop injury that delayed alfalfa maturity (Hintz and Albrecht 1991). Imazamox plus 2,4-DB resulted in less crop injury and a trend for improved first harvest and seasonal forage yield compared to imazamox plus bromoxynil. The seasonal forage yield for glyphosate applied at the two-trifoliate growth stage was similar to forage yields obtained from areas treated with imazamox, imazamox plus 2,4-DB, and imazethapyr alone or in combination with bromoxynil or 2,4-DB.

Economics. First-harvest forage collected from areas treated with herbicide was rated at the supreme grade $(\mathrm{RFV}>185)$ with a 3 -yr average price of $\$ 131 / \mathrm{t}$ (Anonymous 2008). Firstharvest forage collected in areas not treated with a herbicide graded good and was valued at $\$ 90 / \mathrm{t}$. Ward (1994) reported that alfalfa hay with a weed content in excess of $5 \%$ could also be subjected to a discount of from $\$ 9$ to $28 / \mathrm{t}$ because of the concern for animal health because of weeds, even though the forage may have a relatively high RFV. First-harvest forage where no herbicide was applied was estimated to contain $62 \%$ weeds, where glyphosate was applied at the unifoliate growth stage approximately $39 \%$ weeds, and where imazamox was applied approximately $21 \%$ weeds. Therefore, at this level of weed content the forage in all three of these treatments could be docked $\$ 28 / \mathrm{t}$.

Incorporating the dockage for weed content and good grade for the first harvest plus the value of supreme-grade forage for the second and third harvests equated to a gross return of $\$ 1,151 /$ ha in nontreated areas (Table 4). Gross returns were greater for areas treated with a single application of glyphosate at the two-trifoliate growth stage $\$ 1,239 /$ ha, followed closely by the single treatment with imazamox at $\$ 1,222 /$ ha. The lowest gross return of $\$ 1,154 /$ ha was observed where imazamox plus 2,4-DB was applied, which caused crop injury (Tables 2 and 3).

Harvest costs for swathing are priced on a per-hectare basis and do not vary with yield, whereas baling and stacking 
Table 4. Forage yield, costs, and returns for selected herbicide treatments during the first year of establishment at Scottsbluff, NE, 2005 through 2007.

\begin{tabular}{|c|c|c|c|c|c|c|c|c|}
\hline \multirow[b]{2}{*}{ Treatment } & \multicolumn{2}{|c|}{ Rate } & \multirow{2}{*}{$\begin{array}{c}\text { Seasonal } \\
\text { forage yield }\end{array}$} & \multirow{2}{*}{$\begin{array}{l}\text { Gross } \\
\text { return }\end{array}$} & \multicolumn{3}{|c|}{ Selected input costs } & \multirow{2}{*}{$\begin{array}{l}\text { Net } \\
\text { return }\end{array}$} \\
\hline & ae & ai & & & Seed & Herbicide & Harvest & \\
\hline & - & ha & t/ha & & 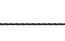 & $-\$ /$ ha & 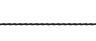 & \\
\hline No herbicide & - & - & 12.0 & $1,151^{\mathrm{a}}$ & 75 & 0 & 413 & 663 \\
\hline Glyphosate (unifoliate) & 0.84 & & 10.0 & 1,212 & 122 & 22 & 360 & 708 \\
\hline Glyphosate (two-trifoliate) & 1.25 & & 9.3 & 1,239 & 122 & 32 & 343 & 742 \\
\hline Glyphosate (two-trifoliate) + & $1.25+$ & & & & & & & \\
\hline glyphosate (eight-trifoliate) & 1.25 & & 9.4 & 1,246 & 122 & 64 & 344 & 716 \\
\hline Imazamox (two-trifoliate) & & 0.036 & 9.9 & 1,222 & 75 & 48 & 356 & 743 \\
\hline Imazamox $+2,4-\mathrm{DB}$ (two-trifoliate) & & $0.036+0.56$ & 8.8 & 1,154 & 75 & 67 & 324 & 688 \\
\hline Standard error & & & - & 60 & - & - & - & 46 \\
\hline
\end{tabular}

${ }^{\mathrm{a}}$ The value of forage in areas not treated with a herbicide was determined in the following manner (first harvest yield of $6.1 \mathrm{t}$ valued at $\left.\$ 62 / \mathrm{t}=\$ 378\right)+($ second harvest yield at $3.0 \mathrm{t}$ valued at $\$ 131 / \mathrm{t}=\$ 393)+($ third harvest yield at $2.9 \mathrm{t}$ valued at $\$ 131 / \mathrm{t}=\$ 380)=\$ 1,151 / \mathrm{ha}$.

expenses are priced by the bale or indirectly by the $t$ of forage. Therefore, higher forage yields resulted in an increase in harvest costs (Table 4). A single glyphosate application had a lower herbicide cost compared to imazamox, but the seed cost for the glyphosate-tolerant alfalfa seed was $63 \%$ greater than the nonglyphosate-tolerant seed. Subtracting selected input costs from the gross return resulted in the net return for each of the treatments. A single application of glyphosate at $0.84 \mathrm{~kg} / \mathrm{ha}$ applied at the unifoliate growth stage controlled $67 \%$ of the weed population and resulted in a net return of $\$ 708 / \mathrm{ha}$. Increasing the glyphosate rate to $1.25 \mathrm{~kg} / \mathrm{ha}$ and delaying the application until alfalfa had reached the twotrifoliate growth stage further improved weed control to $83 \%$ and increased net return to $\$ 742 / \mathrm{ha}$. Applying two applications of glyphosate at $1.12 \mathrm{~kg} / \mathrm{ha}$ at the two- and eight-trifoliate growth stages resulted in $87 \%$ weed control but increased herbicide costs reduced the net return to $\$ 716 /$ ha. The net return per hectare from a single treatment with glyphosate applied at the two-trifoliate growth stage with a glyphosate-tolerant alfalfa variety or with imazamox with a conventional alfalfa variety were $\$ 742$ and $\$ 743$, respectively, which suggests the two technologies were similar. However combining imazamox with 2,4-DB to obtain improved weed control resulted in alfalfa injury, which reduced the net return to $\$ 688 / \mathrm{ha}$.

The profit potential for the producer in utilizing conventional or glyphosate-tolerant alfalfa weed control programs seems to be dependent on the alfalfa market. If alfalfa is utilized in a market where no premium is paid for alfalfa quality (feeder cattle) it may be more economical to implement weed control treatments that maximize seasonal yield, assuming the weeds do not have forage quality concerns such as toxins or high nitrates. In contrast, if forage is utilized in a market where forage quality and the absence of weeds is important (dairy cattle), then removing the majority of the weeds with a conventional weed control program or a glyphosate-based program can both be equally economical to the alfalfa producer. This experiment did not address forage production and weed control in the years following the alfalfa establishment year. Some researchers have speculated that alfalfa free from weed competition will produce more biomass and alfalfa stands will last longer; further research is needed to examine these theories.

\section{Sources of Materials}

${ }^{1}$ Glyphosate-tolerant alfalfa seed 'RR04BD-2411' and 'Rebound 4.2 ' conventional alfalfa variety, Forage Genetics, West Salem, WI 54669 .

${ }^{2}$ The Tye Company, P. O. Box 218, Lockney, TX 79214.

${ }^{3} 11002$ VS nozzle tips, Tee Jet Spraying Systems Co., Wheaton, IL 60188 .

${ }^{4}$ Plot swather, Kincaid Equipment Manufacturing, Haven, KS 67543.

5 PROC MIXED procedure, SAS Institute Inc., 100 SAS Campus Dr., Cary, NC 27513.

\section{Acknowledgments}

This study was supported in part by funds provided through the Hatch Act, USDA. Additional support was provided by Monsanto.

\section{Literature Cited}

Anonymous. Livestock and Grain Market News. 2008. USDA Agriculture Marketing Service. http://marketnews.usda.gov/portal/lg. Accessed: March 5, 2008.

Becker, R. L., C. C. Shaeffer, D. W. Miller, and D. R. Swanson. 1998. Forage quality and economic implications of systems to manage giant foxtail and oat during alfalfa establishment. J. Prod. Agric. 11:300-308.

Canevari, W. M., S. B. Orloff, R. N. Vargas, and K. J. Hembree. 2003. Raptor, a new herbicide for alfalfa weed control. Proc. Calif. Weed Sci. Soc. 55:107-111.

Cords, H. P. 1973. Weeds and alfalfa hay quality. Weeds 21:400-401.

Curran, B. S., K. D. Kephart, and E. K. Twidwell. 1993. Oat companion crop management in alfalfa establishment. Agron. J. 85:998-1003.

Fischer, A. J., J. H. Dawson, and A. P. Appleby. 1988. Interference of annual weeds in seedling alfalfa (Medicago sativa). Weed Sci. 36:583-588.

Gomez, K. A. and A. A. Gomez. 1984. Statistical Procedures for Agricultural Research. New York: Wiley. 680 p.

Hintz, R. W. and Albrecht, K. A.. 1991. Prediction of alfalfa chemical composition from maturity and plant morphology. Crop Sci. 31:1561-1565.

Jeranyama, P. and A. D. Garcia. 2004. Understanding relative feed value (RFV) and relative forage quality (RFQ). South Dakota State University Extension Bulletin 8149.3 p.

Jose, H. D. and S. Malchow. 2006. 2006 Nebraska Farm Custom Rates-Part I. Cooperative Extension Circular EC823. Lincoln, NE: University of Nebraska. $10 \mathrm{p}$.

Marten, G. C. and R. N. Andersen. 1975. Forage nutritive value and palatability of 12 common annual weeds. Crop Sci. 15:821-827.

McCarty, M. K. and P. F. Sand. 1961. Chemical weed control in seedling alfalfa. III. Effect of some herbicides on five varieties. Weeds 9:14-19. 
McCaslin, M., S. Fitzpatrick, and S. Temple. 2000. Roundup ready alfalfa: progress report. Page 245 in Proceedings of the 29th National Alfalfa Symposium and 30th California Alfalfa Symposium, Las Vegas, NV. Davis, CA: Department of Agronomy and Range Science Cooperative Extension, University of California.

McCordick, S. A., D. E. Hillger, R. H. Leep, and J. J. Kells. 2008. Establishment systems for glyphosate-resistant alfalfa. Weed Technol. 22:22-29.

Nelson, K. A., K. A. Renner, and D. Penner. 1998. Weed control in soybean (Glycine max) with imazamox and imazethapyr. Weed Sci. 46:587-594.

Orloff, S. B., R. N. Vargas, W. M. Canevari, and K. J. Hembree. 2003. Progress in Roundup Ready alfalfa. Pages 112-116 in Proceedings for the 33rd California Alfalfa \& Forage Symposium, Monterey, CA. Davis, CA: Department of Agronomy and Range Science Cooperative Extension, University of California. Peregrine, E. K. and R. F. Norris. 1988. Environmental modification of seedling alfalfa, Medicago sativa, tolerance to bromoxynil. Weed Sci. 36:671-677.

Selley, R. A., T. Barrett, R. N. Klein, P. Hay, T. Holman, K. Jarvi, R. Seymour, and G. Zoubek. 2006. Nebraska Crop Budgets. Cooperative Extension Circular EC06-872-S. Lincoln, NE: University of Nebraska. 42 p.
Simmons, S. R., C. C. Sheaffer, D. C. Rasmusson, D. D. Stuthman, and S. E. Nickel. 1995. Alfalfa establishment with barley and oat companion crops differing in stature. Agron. J. 87:268-272.

Tonks, D., L. S. Jeffery, and B. L. Webb. 1991. Response of seedling alfalfa (Medicago sativa) to four postemergence herbicides. Weed Technol. 5:736738.

University of Nebraska. 2007. 2007 Guide for Weed Management in Nebraska Cooperative Extension Circular EC130. Lincoln, NE: University of Nebraska. 192 p.

Ward, C. E. 1994. Price and quality relationships for alfalfa hay. J. Am. Soc. Farm Manag. Rural Appraisers 58:130-134.

Wilson, R. G. 1986. Weed control in irrigated seedling alfalfa (Medicago sativa). Weed Sci. 34:43-426.

Wilson, R. G. 1994. Effect of imazethapyr on legumes and the effect of legumes on weeds. Weed Technol. 8:536-540.

Received June 3, 2008, and approved January 27, 2009. 